LBL 7896

4 of 6 c. 2 UC-13

\title{
ENERGY CONSERVATION: POLICY ISSUES AND END-USE SCENARIOS OF SAVINGS POTENTIAL
}

\section{not? 198}

PAR 4

ENRERY EFFICIENT TRERPTIOMAL TRAMEL

\section{TWO-WEEK LOAN COPY}

This is a Library Circulating Copy which may be borrowed for two weeks. For a personal retention copy, call Tech. Info. Dívision, Ext. 6782

September 1978

\section{Lawrence Berkeley Laboratory} University of California, Berkeley 


\section{LEGAL NOTICE}

This report was prepared as an account of work sponsored by the United States Government. Neither the United States nor the Department of Energy, nor any of their employees, nor any of their contractors, subcontractors, or their employees, makes any warranty, express or implied, or assumes any legal liability or responsibility for the accuracy, completeness or usefulness of any information, apparatus, product or process disclosed, or represents that its use would not infringe privately owned rights.

Printed in the United States of America

Available from

National Technical Information Service

U. S. Department of Commerce

5285 Port Royal Road

Springfield, VA 22161

Price: Printed Copy, $\$ 5.25$ Domestic; $\$ 10.50$ Foreign

Microfiche, \$3.00 Domestic; $\$ 4.50$ Foreign 


\title{
ENERGY CONSERVATION: POLICY ISSUES \\ AND END-USE SCENARIOS OF \\ SAVINGS POTENTIAL
}

\author{
LBL PROJECT STAFF \\ Peter Benenson \\ Ricardo Codina \\ Bonnie Cornwall \\ David Dornfeld \\ Barbara Greene \\ Jon Elliott \\ Willett Kempton \\ Catherine Langlois \\ Harold Nelson \\ John Nides \\ Forest Rouse \\ Carola Sullam \\ CONSULTANTS \\ Richard Barnes \\ Dow Chemical, USA \\ Norman M. Bradburn \\ Department of Behavioral Sciences \\ University of Chicago \\ Lawrence Berkeley Laboratory
University of California, Berkeley \\ September 1978
}

Prepared for the U.S. Department of Energy under Contract W-7405-ENG-48 submitted to Dr. Clark Bullard Director, office of Conservation and Advanced Energy Systems Policy

U.S. Department of Energy

PRINTED ON RECYCLED PAPER 
TABLE OF CONTENTS

\section{PART}

1. SUMMARY

2. TRADEOFFS OF MUNICIPAL SOLID WASTE PROCESSING ALTERNATIVES

1) Economics of Garbage Collection

2) Mechanical vs. Home Separation of Recyclables

3. POLICY BARRIERS AND INVESTMENT DECISIONS IN INDUSTRY

1) A Methodology for the Identification of Potential Barriers to Industrial Energy Conservation

2) The Process of Industrial Investment Decisionmaking

4. ENERGY EFFICIENT RECREATIONAL TRAVEL

1) An Information System to Promote Energy Efficient Recreational Travel

2) Recreational Travel: National Importance and Individual Decision-making

5. ENERGY EFFICIENT BUILDINGS

1) The Causes of Litigation Against Energy Conservation Building Codes

2) A Description of the Building Process

6. END-USE ENERGY CONSERVATION DATA BASE AND SCENARIOS

1) Residential

2) Commercial

3) Transportation

4) Industrial 


\section{FOREWORD}

The enclosed work is based upon our previous research during this fiscal year, contained in "Construction of Energy Conservation Scenarios: Interim Report of Work in Progress", LBL 7834, June 1978. The focus of our current work was determined in consultation with the Director and staff of the Conservation and Advanced Energy Systems Policy office, DOE, following their review of our interim report. At that point we agreed on several guidelines for our subsequent work:

1. Take a wholistic view of energy conservation policies by describing the overall system in which they are implemented;

2. Provide analytical tools and sufficiently disaggregated data bases that can be adapted to anwer a variety of questions by the users;

3. Identify and discuss some of the important issues" behind successful energy conservation policy;

4. Develop an energy conservation policy in depth.

In addition to these guidelines, we selected five subjects to investigate.

1. Recycling: an analysis of the energy, economic, and environmental tradeoffs between landfill and combined programs of resource recovery and energy generation from waste.

2. Industrial Decision-Making: a methodology to identify potential barriers to energy conservation by analyzing how a conservation measure's attributes interact with the characteristics of an industrial subsector.

3. Recreational Travel: information strategies to effect a modal shift to public transit for the recreational trip.

4. Residential and Commercial Buildings: an examination of court cases against new energy efficient building codes and suggestions for avoiding future litigation.

5. End Use Energy Conservation Data Base: completion of energy conservation scenarios by calculating the energy conservation potential of specific measures applicable to particular end uses.

Our current work results from the application of the overall guidelines to the above subjects. For example, we have described the system in which each policy or issue is set by the use of flowcharts and accompanying text. In some cases, the flowchart describes a physical activity (constructing buildings or recycling waste materials). In other cases, it describes a decision-making process (industrial investment or transportation modal choice). 
We have provided disaggregated quantitative data wherever they are relevant--recycling, recreational travel, industrial decision-making, and the end use scenarios. We have discussed several policy issues for which these data are relevant:

1. What are the tradeoffs between landfill and combined resource recovery-garbage to energy programs.

2. What are the stated and underlying causes of law suits against building codes.

3. How can the present modal distribution that is heavily weighted toward the automobile be shifted to public transit for the recreational trip.

4. What are the conditions that present barriers to energy conservation investment in the industrial sector.

In the case of recreational travel, we have developed a specific policy to link national parks with public transit.

Our results for each of the five subjects are bound separately; the subjects do not readily lend themselves to integration and the DOE staff did not think it would be useful to attempt one. We have issued a separate summary volume for those who want an overview of all the subjects investigated. 


\section{ACKNOWLEDGMENTS}

Although a number of individuals contributed to this work, a few people were primarily responsible for researching and writing each part:

Part 2 Ricardo Codina

Catherine Langlo1s

Part 3 David Dornfeld

Richard Barnes

John Nides

Jon Elliott

Part 4 Bonnie Cornwall

Carola Sullam

Part 5 Willett Kempton

Bonnie Cornwall

Harold Nelson

Part 6 David Dornfeld

Barbara Greene

Richard Barnes

Forest Rouse

We wish to thank those who provided and criticism of our drafts. They are listed at the end of the part to which they contributed. We are also grateful to Katherine Graham and Henrietta Louis for many hours of careful typing and to Alan Char for computer programming. 
* 
TABLE OF CONTENTS

OVERVIEW

page

SECTION 1: INFORMATION SYSTEMS TO PROMOTE ENERGYEFFICIENT RECREATIONAL TRAVEL

I. SUMMARY OF INITIATIVE

II. INITIATIVE: AN INFORMATION SYSTEM FOR THE

NATIONAL PARK SERVICE

A. THE INSTITUTIONAL ENVIRONMENT

B. INFORMATION PROBLEMS

C. INQUIRY-RESPONSE SYSTEM

D. BROCHURES AND PAMPHLETS

E. MEDIA CAMPAIGNS

F. ENERGY IMPACTS

G. DEPARTMENT OF ENERGY'S ROLE

SECTION 2: RECREATIONAL TRAVEL--NATIONAL IMPORTANCE AND INDIVIDUAL DECISION-MAKING

I. IMPORTANCE AND IMPACT OF THE RECREATIONAL TRIP 17

A. GROWTH OF RECREATIONAL TRAVEL 17

B. THE AUTOMOBILE AS THE PREFERRED MODE OF TRAVEL

C. LACK OF POLICY FOR RECREATIONAL TRAVEL

D. IMPORTANCE OF THE RECREATIONAL TRIP IN TRANSPORTATION

E. FOCUS OF POLICY RECOMMENDATIONS 20

II. WEEKEND TRAVEL

A. TRIP PURPOSE

21

B. TRIP ACTIVITIES

C. MODAL CHANGE AND VEHICLE OCCUPANCY

D. CHANGES IN WEEKEND TRAVEL

III. THE FLOWCHART: DECISION-MAKING FOR THE

RECREAT IONAL EXPERIENCE

A. AN AID TO POLICY DESIGNERS

B. ORIENTATION OF PREVIOUS RESEARCH

24

C. FOCUS OF THIS INVESTIGATION: USER NEEDS 24

D. THE 5 PHASES OF THE RECREATIONAL EXPERIENCE 25

E. THE SYSTEM

F. THE ENVIRONMENT

IV. POLICY DEVELOPMENT FOR PHASE 1 "PLANNING" 28

A. INFORMATION PROBLEMS CONCERNING MODAL CHOICE 28

V. OBJECTIVES AND STRATEGIES FOR "PLANNING"

A. CREATE AND/OR STRENGTHEN LINKS BETWEEN

TRANSIT INFORMATION AND OTHER SOURCES

B. DESIGN A CENTRALIZED SYSTEM FOR RECREATION/ TRANSIT INFORMATION

C. STRESS TRANSIT'S RECREATIONAL POTENTIAL IN

THE INFORMATION AND MARKETING SYSTEMS 
OVERVIEW

Energy consumed for recreational travel is an important component of total transportation energy consumption. This report contains the design of a specific policy that addresses energy conservation in recreational travel. The policy is denoted as an "Information System for the National Park Service." This work is based on our prior examination of the characteristics of the recreational trip and decision-making for the recreational experience. The examination revealed which aspects of the recreational travel system needed to be addressed to encourage energy-efficient modal decisions for recreational travel.

This policy is briefly described in section 1, the "Summary of Initiative." A more detailed discussion of the policy follows. The material which led to the policy's formation is developed in section 2:

- Importance and Impact of the Recreational Trip

-Weekend Travel

-The Flowchart: Decision-Making for the Recreational Experience

-Policy Development for Phase 1 "Planning the Trip" -objectives and Strategies for "Planning the Trip". 
SECTION 1: INFORMATION SYSTEMS TO PROMOTE

ENERGY EFFICIENT RECREATIONAL TRAVEL

I. SUMMARY OF INITIATIVE

INITIATIVE AREA: Recreational Transportation

TITLE: An Information System to Link Recreation/Transit Information

TIME PERIOD: Short Term $(78-85)$

PROBLEM: Recreational travel could account for between 15-30 percent of all personal automobile use; until recently, there has been no policy addressing this trip type. The automobile is the preferred mode for recreational use on weekend trips, but its use has been declining slightly since 1972. The use of buses and trains has increased, though they still account for only 5 percent of weekend trips. The problem is how to facilitate a modal shift to a more efficient means of transportation to, from and within the recreational area.

An examination of the traveler's decision-making process reveals that information is one of the weak links in the modal choice decision. Information on recreational areas is biased towards the auto. Transit information reaches the traveler too late to influence his/her modal decision; it does not promote the "fun" aspect of the recreation trip, but merely gives routes, schedules and fares. An improvement is needed in the focus and timing of information so that recreational transit becomes a "real choice". Congress has just recently passed legislation, P.L. 95-344, mandating that the National Park Service (NPS) consider problems of access to, from and within the parks, particularly for non-auto modes. Included in the mandate is the authorization for an information program.

INITIATIVE DESCRIPTION: The information system we have designed has three major components whose administrative responsibility lies with the NPS. They are 1) an inquiry and response system with a toll-free 800 telephone number, mail-in service and walk-in centers; 2) brochures and pamphlets designed to promote recreational transit and 3) media campaigns to appeal to specific market segments most amenable to transit.

The objectives of the information system are a) to create and/or strengthen the links between transit information and that of other recreational sources; b) to design a 
centralized information system and c) to stress the recreational potential of transit trips.

END USE AFFECTED: Recreational Transportation

MAJOR BENEFITS AND IMPACTS:

1. Decrease gasoline consumed by automobiles for

recreational purposes.

2. Provide improved access to recreational areas for transit-dependent populations.

3. Decrease congestion on recreational access routes.

4. Preserve the environmental integrity of natural areas by decreasing parking lot requirements and abating air pollution.

Energy Impacts: The energy impacts are difficult to ascertain for two reasons. First, the base data on transportation for recreational purposes are presently unavailable in enough specificity to evaluate energy consumption. Within park boundaries, no figures exist concerning daily miles travelled per vehicle type. Transportation studies similar to those presently being conducted in Yellowstone could reveal, for example, how much energy would be saved if 50 percent of in-park recreational vehicle miles were travelled by shuttle instead. Secondly, it is difficult to predict the modal shift resulting directly from the information system.

IMPLEMENTATION AND ADMINISTRATION:

Steps

Initiate PLANNING PROCESS to bring together actors from the public and private spheres to develop transportation alternatives and design an information system.

Develop guidelines to carry out P.L. 95-344.

Conduct transportation studies and public hearings concerning both transportation and the information system. Hire staff with expertise in transportation. Note: This process will be constrained by Congressional appropriations.

Key Actors: Congress, NPS (at national, regional, and local levels), park concessionaires, local transit authorities, private transportation companies and the public.

Develop the STRUCTURE of the INFORMATION SYSTEM.

Facilitate interchange between concerned actors to work out the particular structure for the system.

Design media programs and brochures.

Hire staff with experience in marketing, publicity, media, community relations, graphics, etc.

Note: Initial information will address existing transit options. As transportation plans are finalized, information will be updated.

Key Actors: Same as above 
IMPLEMENTATION OF CENTRALIZED SYSTEM with final responsibility for coordination lying with the NPS. Staff will be needed on a permanent and seasonal basis to respond to requests.

Key Actors: NPS

MONITORING AND EVALUATION of information system. Continual feedback will be necessary as well as formal review. Key Actors: NPS

BARRIERS AND OPPOSITION: The key to implementation will be the cooperation among the groups involved. For this reason, it is essential to involve all actors early in the planning process. The designation of a single information center will require an agreement among the agencies presently distributing information and possibly a transfer of funds. Transit authorities may not be anxious to join in and take additional responsibilities.

Transit dependent population groups-particularly the elderly and the disabled -for whom services are designed, will be quite supportive. General taxpayers may not initially appreciate the inconveniences to recreational auto travel that might result from transit policies (e.g. funds being channeled to transit rather than to additional parking lots.)

COST: The breakdown of costs is somewhat open-ended. P.L. 95-344 authorizes \$1 million for fiscal year 1979; $\$ 2$ million for fiscal year 1980 ; and $\$ 3$ million for fiscal year 1981. The actual funds available depend upon Congressional appropriation, and obviously not all of the appropriated monies will go to the information program. The level of service offered by the system can vary to take advantage of any available funds. Not all support need come from Congress; some could be provided by park concessionaires and transit authorities, possibly in the form of in-kind services, such as brochures and staff. 
II. AN INFORMATION SYSTEM FOR THE NATIONAL PARK SERVICE

\section{A. THE INSTITUTIONAL ENVIRONMENT}

Our analysis of the flowchart, Figure 2, revealed that transit information needs to be injected early into the planning process, but this is complicated by the sources of information on recreational areas and transit services. The many institutions involved and the diversity of their responsibilities make policies for recreational travel difficult to effectuate. The problem is not simply a lack of coordination among many different groups but the absence of an institutional mechanism to bring various actors together and help them adopt to changing conditions. Without this institutional focus, the interactions between transit and recreational agencies have been haphazard and contradictory. Consequently, policy development for recreational travel fell between the cracks. Although a component of both recreation and transportation, neither industry took responsibility for recreational travel. Very recently, however, Congress has taken the first step toward changing this situation, with the passage of P.L. 95-344. This legislation gives formal authority to the National Park service to develop strategies for recreational travel to natural, scenic, historic, and park areas. Although theoretically the policy developed below could be implemented by a number of agencies including DOE, the policy is couched primarily in terms of NPS's role because of this recent legislation. DOE'S role is discussed later in the section after the major structure of the policy has been delineated.

\section{The National Park Service: Previous Mandate}

In the past, the purpose of the National Park Service (NPS) was to preserve resources rather than to bring people into park areas. In 1972, there was a slight change in the NPS's mandate as Congress passed legislation (P.L.92-589) establishing the Golden Gate National Recreation Area and the Gateway National Recreation Area - the largest national parks situated near major metropolitan centers (San Francisco and New York). This law recognized the need for parks proximate to urban residents, many of whom did not have access to automobiles. It also mandated a study on the transportation needs of park visitors.

In the San Francisco Bay area, NPS and local transit authorities worked together on a demonstration project for recreational travel: on weekends, established bus service was extended to a few points within the Golden Gate National Recreational Area. A demonstration grant from the NPS subsidized the weekend extension the first year. This service was successful in attracting ridership and 
widespread public support, particularly among transitdependent population, such as the elderly. Given the initial popularity of the project, the subsidy was continued the following year by the local transit districts, in the hope of eventually obtaining additional funds from NPS. An extensive study on travel alternatives to the Golden Gate National. Recreational Area recommended that NPS continue to share in the responsibility of transporting people to, from, and within the park.

However, the NPS was constrained by the office of Management and Budget (OMB). The OMB Head Examiner for the NPS budget stated that the Park Service had neither the responsibility nor the right to carry people any distance to its recreational areas (Golden Gate Recreational Travel Study Staff Report 4, 1976: 25-26).

\section{Recent Developments: P.L. $95-344$}

On August 15, 1978, Congress passed P.L. 95-344, legislation authorizing the NPS to formulate transporation plans and implement transportation programs. The purpose of this act is to encourage access to recreational areas in a manner consistent with the two goals of park preservation and energy conservation - i.e. to support modes other than the private automobile for access to and within national parks. For the first time, that NPS has the authority and the funding to deal with issues outside park boundaries - in particular, transportation to the parks.

Under the act, NPS is authorized to: contract with public or private agencies or carriers to provide transportation services; operate such services directly in the absence of suitable agencies and carriers; acquire by purchase, lease, or agreement the capital equipment necessary for such services; establish information programs to notify the public of alternative travel modes to national parks.

P.L. 95-344 represents an important first step in the development of a national policy for recreational travel. NPS has hired transportation planners and is formulating strategies to implement its legislative mandate. Discussions with NPS personnel indicate that there are three potential areas of application for these new policies (Bowser, $9 / 8 / 78$ ):

- for park sites which are limited in space, and where NPS can no longer take land to accommodate automobiles; the use of these facilities is becoming more and more transit-dependent.

-for park sites to which access roads are severely congested.

- for the population in general and for specific groups in particular, i.e. the transit-dependent. The long 
range effort will be directed to the general population, which has lost its "transit sophistication."

\section{B. INFORMATION PROGRAMS}

Presently, it is actually possible to reach certain national parks and to travel within them by transit. The problem is that most people are not aware of these transit systems and would not be so unless they actively sought the information. Much information is currently available, but it reaches the recreationist only if $s / h e$ specifically asks for it. NPS recognizes the deficiencies in its publicity and outreach network, but is still not sure how much of the new monies could be spent on promotion.

The information system is a crucial component of any recreational travel policy which NPS should not overlook or treat scantily. The most innovative and energy-conserving transportation system will be neglected and/or underutilized if recreational travellers are not made aware of and encouraged to use it. A strong information system supporting transit would protect the natural and scenic qualities of the parks by discouraging automobile traffic.

Although the following strategies are directed at the NPS, we wish to emphasize that this agency is only one of many involved actors. The NPS will have to work in partnership with other federal agencies (such as DOT or DOE) as well as with the private sector. Issues related to recreational travel fall within the responsibility of various actors, and NPS can not be expected to solve singlehandedly all recreational travel problems.

\section{Underlying Principles}

The construction and analysis of the flowchart has revealed certain principles and concepts which should inform the design of an information system:

-Inject transit information early in the planning process.

-Reduce the number of information sources for the recreationist to contact.

-Include data relevant to all decisions the recreationist must make.

-Utilize existing information programs of transit and recreation agencies.

-Use a variety of promotional methods and information formats to meet the needs of the various market segments.

-Consult the operating staff in the design of the system. 


\section{Major Components}

In the context of the above discussion, we suggest three components for the NPS to develop in its initial information dissemination program: inquiry and response system; brochures and pamphlets; media campaigns.

\section{INQUIRY AND RESPONSE SYSTEM}

The inquiry and response system is the more general, overall mechanism to centralize the multiple sources of recreational and transit information. Its operation would include some of the components mentioned above, such as brochures and pamphlets. A variety of promotional techniques, including handouts, $T V$ and radio publicity, speaker programs, etc., will be necessary to make people aware of the system and to prompt initial inquiries.

\section{Design of Service}

The NPS should develop a telephone and mail service which disseminates information on the park areas. The system would be organized around a core of pre-packaged materials describing the requested recreational area and transit access. Materials would be mailed to requesters, with specific questions answered directly.

a) The NPS should organize a telephone service, consisting of a toll-free 800 number, preferably an acronym such as FUNTRIP. The service should include regional operators for specific parks or groupings of parks. These staff people would be very familiar with the parks. services and could respond to individual travel and recreational concerns. They would supplement the pre-packaged, hard-copy material previously sent in the mail and provide current information on weather, special activities, etc.

b) The NPS should organize a mail service, consisting of a pre-printed card, which might be postage paid. Such cards would have blanks for name, address, recreation area, travel constraints and requirements and special information. The toll-free number (see "a" above) would also be displayed. Cards could be included in travel magazines, Sunday newspapers, newsletters, etc. They could also be available in public places, such as post offices, libraries, and supermarkets (Economic Research Associates 1975:141). This does not mean that NPS would discourage independent written inquires; the pre-printed card would simply facilitate handling and response.

c) Finally, the NPS should provide walk-in service at each park, for example, a visitors'center. The center 
should emphasize transit as the logical and pleasant choice for travel to, from and within the park; however, the service should also recognize the information needs of nontransit travellers. Graphic displays on transit should be prominently displayed, easy to read, and up-to-date, with easy directions to transit stops.

\section{Organization and Coordination}

The NPS would have direct responsibility for developing the system and for providing full time and seasonal staff. If the NPS publicizes services provided by park concessionaires, then the latter should also help support the information system, either financially or with personnel.

Since the NPS anticipates using existing transit services as much as possible (Bowser at NPS, 9/1/78), the agency will have to include local transit authorities when designing the information system. Their input should consist primarily of route and scheduling details, rather than funds. It is probable that at least some of the money necessary, for example, to extend transit service, could come from the funds appropriated under P.L. 95-344. However, transit authorities might be able to donate some staff time to the information system. It is also likely that NPS will need to involve private companies, such as Greyhound in the design of the information system. In the Bay area, six public and private transit operators have formed an institutional mechanism, the Regional Transit Association of the Bay Area, that is already beginning to focus on off-peak travel, which includes recreation. The NPS should tap into this and similar organizations, since an effective information system will necessarily require a cooperative effort on the part of many actors (Mills at AC Transit, 9/25/78).

The NPS should not design its inquiry and response system without consulting the concerned parties. One organization or agency could potentially work against the whole system or not cooperate in coordinating services if they felt inadequately represented. For example, the current antagonism between the NPS and certain park concessionaires forces recreationists to go to two separate agencies to obtain information about a specific párk.

The staff of the information system must be committed to the idea of utilizing transit in order to communicate this idea effectively to the public. This is a critical factor with the telephone staff in particular, who will have contact with recreationists when their plans are most fluid. Their ability to promote transit might prove to be a crucial variable in the success of the program. 


\section{BROCHURES AND PAMPHLETS}

\section{Design of Service}

Brochures and other printed matter are a critical component of any information system. Those recreationists interviewed in a Golden Gate Recreational Travel Study stated that they do read brochures and seek them out actively (Economic Research Associates 1975:140).

All NPS mailings should include a pamphlet or brochure with transit information. Most NPS printed material now consists solely of on-site maps, historical information, points of interest, etc. The NPS currently provides transit information only if it is specifically requested. (The primary exception to this are the materials provided by the Golden Gate Recreational Area, which notify people about transit possibilities.) Instead, it should be available as part of the standard "package". Transit information should be prominently displayed, extremely specific, and up-todate. Routes, departure and arrival points, time schedules, fares, and telephone numbers are the minimum information necessary. The brochures should also inform the public of any on-site transit (e.g. park shuttle) and how it links with access transit.

b) Transit information should also be included with campsites and lodging information. People who car-camp are not likely to switch; however, park visitors using NPS accommodations might not need their automobiles. NPS should encourage recreationists to consider taking transit by:

-stressing the negative aspects of automobile travel, such as crowded access roads, lack of parking, environmental impacts, hazardous road conditions, etc.

- making transit and lodging part of an inclusive "package deal", a practice common in the private recreational sector (DeBell at MCA, 9/8/78).

c) These brochures should also supply as much information as possible about the site, so recreationists will not feel compelled to maximize their flexibility by traveling in an auto. Necessary details include:

-weather and topographic conditions, so recreationists can bring and wear appropriate shoes and clothing.

-availability of food and beverage outlets, toilets, cooking facilities, showers, lockers, etc.

-availability of rental equipment, such as bicycles, boats, roller skates, etc.

-park rules and restrictions.

d) Information should be presented in a visually pleasing graphic format. Color pictures are an essential component. The cover will influence whether the brochure is 
picked up. References to busses, either in the cover picture or the title, will deter the dissemination of The brochure (Economic Research Associates 1975: 140-141). Within the brochure, transit schedules should be highlighted in a box, for easy identification by the recreationist.

e) On-site materials may need another format to persuade visitors to pick it up. For example, at Yosemite, MCA, the concessionaire, and NPS disseminate information about the park very effectively in a newspaper format. Transit information should again be highlighted visually (e.g. boxed).

\section{Organization and Coordination}

The NPS would have direct responsibility for developing and distributing the promotional material. Local transit agencies would have input on routing and scheduling. The particular arrangement with the concessionaires would need to be determined. In any event, the NPS should require that transit information be prominently displayed in any promotional material for the park.

Distribution should go beyond responding to requests. An aggressive and personalized outreach program is also desirable. This might include direct mailings to community and neighborhood organizations, environmental and conservation groups, recreational equipment outlets, county and municipal governments, etc.

The NPS will have to increase their coordination with transit agencies, common carriers, and other actors in the recreational sector. Local staffs will probably have to retain a transportation planner to act as a liaison. This will not be necessary for every national park, since transit access is not a feasible modal alternative to all sites. However, a transportation planner will probably be needed at:

-the most heavily visited parks, where air pollution and traffic congestion are severe;

-parks proximate to major metropolitan areas (e.g. within a 100-200 mile.radius);

-parks most attractive to transit-dependent populations, such as the elderly (e.g. historical sites vs. wilderness areas). 


\section{E. MEDIA CAMPAIGNS}

\section{Design of Service}

The promotional techniques utilized by the NPS should take advantage of the predominance of personal communications between friends for information on both recreational areas and transit. Impersonal sources may make people aware of alternatives but do not generally prompt changes in behavior. Additionally, the NPS's campaign should recognize the tendency for peer-groups of similar ages and/or interests and activity patterns to travel together. A variety of media campaigns, suggested below, would meet these diverse requirements.

a) The NPS's information system should create an image for transit to and in the parks. It should publicize a logo with which the public could become familiar. The logo should prevail throughout the park system and be displayed on brochures, posters, busses, busstops, etc. The symbol would identified with a pleasant and reliable transit system.

b) The speakers bureau would orient specific market segments to recreational transit. Speakers are an effective promotional technique because they can directly answer spur-of-the-moment or unusual questions. They can also encourage citizen participation in the design and evaluation of services. The NPS should target this program to those groups most likely to utilize transit, such as the elderly or conservation organizations.

c) NPS's information system should prepare media releases to promote articles in local newspapers, particularly the sunday travel section and in travel magazines, on recreational transit developments and opportunities. These articles would incorporate transit details, such as routes and time schedules, in their description of specific recreational areas. The 800 telephone number and a copy of the inquiry card should also be included.

Such articles would be particularly valuable if they focussed on the transit mode itself as a rationale to go to a particular area. The publicity for doubledecker busses and cable cars has brought people to London and San Francisco for many years. These transportation systems have become synonymous with the place. The media articles should stress the benefits of the transit system-the "fun" aspects of the trip, not worrying about parking and congestion, social camaraderie--over its mere presence.

d) Many people now frequently use the telephone book as a source of information for trip planning, as local transit 
information is already available in the yellow pages. NPS should take advantage of this existing information conduit by inserting a map displaying transit possibilities to national parks located within 100-200 miles of urban areas (e.g. the transit map to Yosemite would be displayed in the San Francisco and Los Angeles telephone Books). The 800 telephone number for national information should be listed on the maps as well as in appropriate spots throughout the "white" and "yellow" pages. The inquiry card itself could be on the inside cover of the telephone book with perforations allowing it to be torn out. The cover of the telephone book in appropriately situated cities could also highlight park transit.

e) People can presently obtain information on the condition of sites, for example through ski and surf reports, on the telephone and radio. These messages could include transit information as well, added briefly at the end. Ideally, the telephone and radio messages should mention frequency of service and routes, but if time is limited, the 800 telephone number would suffice.

\section{Organization and Coordination}

The media campaign is a component of the overall information system; the NPS should integrate the three components discussed in this section to realize cost savings in personnel, promotion, and miscellaneous expenses. Since the NPS's previous orientation has been somewhat narrow, the agency should commit itself fully to its new mandate by devoting staff time directly to the information program. This may involve retaining full-time personnel, who are responsible for and have expertise in the agency's information program. Staff need to be aggressive enough to contact and solicit the cooperation of a wide variety of actors, many of whom have had no prior experience or interest in either recreational or transit issues. People well versed in marketing with extensive media experience might well supplement present NPS staff. Other areas of expertise will include graphic design, advertising, communications, and public relations. Staff requirements will include but not be limited to:

-developing a logo and design campaign.

-coordinating information programs with recreation/transit personnel. This would include general orientation for management and operations personnel.

- selecting promotional criteria based upon market segment requirements.

-contacting community groups and coordinating with the speakers' bureau.

-preparing media news releases on recreation transit opportunties. 
-establishing a distribution system for new recreation transit materials.

\section{F. ENERGY IMPACTS}

The policy's estimated savings are difficult to assess for two reasons. First, the base data on transportation for recreational purposes are presently unavailable in enough specificity to evaluate energy consumption. Within park boundaries, no figures exist concerning daily miles travelled per vehicle type. Transportation studies similar to those presently being conducted in Yellowstone could reveal, for example, how much energy would be saved if 50 percent of in-park recreational vehicle miles were travelled by shuttle instead. Secondly, it is difficult to predict the modal shift resulting directly from the information system.

In the short run, this policy could result in increased consumption of energy for recreational travel. At present, the energy devoted to recreational travel represents primarily that used by those with access to private vehicles. Encouraging people to ride transit to national parks will result in greater energy use, but not in personal automobile consumption of gasoline. It is personal consumption that is addressed by this policy.

The short-run increase in energy consumption reflects the enhanced accessibility of recreational areas to those who are transit-dependent. If these "new" recreationists use an energy-efficient mode, then the NPS is still within its mandate of increasing access to parks in a manner that is both energy-conserving and park-preserving. To decrease total recreational travel energy, a modal shift from the automobile to public transit must also occur; this is a long-run goal of this recreational transportation policy.

To reach this goal, DOE must help develop a system that is a workable alternative to the automobile. Initially, policy-makers should appeal to the transit-dependent in order to secure ridership and establish the system. In time, as transit becomes a standard feature in recreational areas, automobile travellers may be tempted to leave their cars at home. For example, Yosemite's Master Plan could not suggest removing "day-tripping" automobiles from the Yosemite valley unless a shuttle service had been shown to be viable.

In the short run, DOE should concentrate its efforts in two areas: efficient transit vehicles and on-site travel. As NPS acuqires buses, DOE can suggest the most efficient vehicles and, in conjunction with DOT, might even support the design of such vehicles. Secondly, it is probably 
easier to coax people out of their cars for on-site day trips. In addition, DOE might find it simpler to collect and analyze data on such trips and to determine if energy is indeed being saved.

\section{G. DEPARTMENT OF ENERGY'S ROLE}

Although it is not within the direct mandate of DOE to undertake transportation planning for the national parks, the agency has a number of potential roles regarding this policy.

1. Supplement NPS Funding and Analysis of Park Transportation

The transportation surveys currently being conducted by NPS may not reveal enough information on energy consumption for DOE to evaluate alternative transportation plans. The scope of the surveys ought to include the particular vehcile types, vehicle-miles travelled by vehicle type each day, occupancy per vehicle type, etc. This would enable policymakers to compare modal choices and encourage energyconserving modes where they would result in the greatest savings. This is particularly critical for on-site travel to specific, heavily-used destinaions. DOE's support in this area would free monies from the NPS's transportation surveys into the information system, a critical element for a successful modal redistribution.

2. Coordinate the Informaton System, in particular the Toll-Free Telephone Number

DOE's Solar Division operates a toll-free 800 number for public information on solar energy. This experience might be directly transferable to the information system for recreational transit. Another possibility is to initiate a system similar to the Agriculture Department's experiment in Kentucky which enables farmers to connect their televisions into a computerized "green thumb box" to obtain weather information.

Transit

3. Develop Public Relations Material on Recreational

Involvement by DOE would ensure that the bias of the NPS or other involved agencies does not dominate materials. In addition, the NPS may not feel comfortable taking on a promotional role, since the agency may interpret such actions as more suitable to a chamber of commerce or similar organization. 
4. Initiate a Demonstration Project for Recreational Transit to Determine Energy Savings

A demonstration project would generate "real world" information and would indicate whether or not energy could be conserved. A useful project might be focused on a particular weekend trip, with a specific destination and few on-site transportation requirements. The ski trip fits this description, since the automoile plays a limited role in the actual recreational experience. Both access and on-site transportaton occur at predictable hours; recreationists travel with a standard set of equipment; and accommodations are usually centralized and located near the site.

\section{Advise NPS in its Acquisition of Vehicles}

DOE may be able to suggest and design the most energyefficient vehicles.

SECTION 2: RECREATIONAL TRAVEL

NATIONAL IMPORTANCE AND INDIVIDUAL DECISION-MAKING

\section{IMPORTANCE AND IMPACT OF THE RECREATIONAL TRIP}

\section{A. GROWTH OF RECREATIONAL TRAVEL}

In the United States, decision-makers have often not recognized the importance of recreation as a policy issue. Leisure and recreation are equated with "free time" as opposed to the more meaningful activity, work. (Senate subcommittee on Foreign Commerce and Tourism 1974:39). Problems related to recreation are often considered of secondary importance, to be dealt with only when more pressing concerns are resolved.

On a national level, leisure-related activities have developed into an industry of economic importance. In 1972, expenditures for traveliing to, from and engaging in recreational activity approached $\$ 61$ billion and provided four million jobs. According to the National Tourism Resources Review Commission, leisure and recreation will be a $\$ 127$ billion industry by 1980 (Senate subcomittee on Foreign Commerce and Tourism 1974:22).

An important factor in leisure time is travel - not only in terms of going to and from recreational areas but also as a form of recreation itself. For many people, recreation means travel. According to the 19.72 National 
Travel Survey, persons from two out of three U.S. households took a trip (hereafter defined as being 100 or more miles from home, one way) during the year. Some travelled for business or personal reasons, but almost $54 \%$ of the trips (about 127 million) were devoted to visiting friends and relatives, entertainment, sightseeing, and outdoor recreation. (Preliminary data from 1977 National Travel Survey, First Quarter, seem to support these findings). Surveys indicate that $72 \%$ of all vacationers travel primarily to sightsee (National Advertising Company 1972:1), while 77\% will indulge in "impulse" travel: taking sidetrips to visit places and do things not on the original itinerary, such as a scenic drive or an historic site. (National Advertising Company 1970:2).

Recreational travel is likely to increase in the future. Between 1972 and 1974, despite the Arab oil embargo, the number of trips for pleasure rose by over 37 million, a jump of $30 \%$. (1972 and 1974 National Travel surveys). Now and in the future, recreationists are likely to travel to non-urban areas, such as seashores. This is evident from such recent data as the increase in the number of visits to national park areas (up 12\% between 1975-76; see Goeldner 1977) and in the number of sales of recreational vehicles (an increase of almost $60 \%$ between 1970-73; Motor Vehicle Manufacturers Assoc. 1977:15). A general lack of adequate urban park and recreational facilities also encourages people to use remote public and private recreational sites (Gold 1977:173).

\section{B. THE aUtomobile as the PREFERRED MOde OF TRAVEL}

On most of these leisure trips, the automobile is the preferred mode of travel: the 1977 National Travel Survey shows that $81 \%$ of all trips were made by automobile. For some trips such as skiing, $90 \%$ of all participants arrive by car (Booz, Allen \& Hamilton 1974:27). Such dependence on the car for pleasure travel has diverse and serious impacts: growing levels of air pollution and traffic congestion in both cities and more remote recreational areas; environmental stress, and for some, diminished quality of the onsite recreational experience; and consumption of land and money for the development and maintenance of circulation systems and parking facilities (Gold 1977:173).

Finally, lejsure travel contributes significantly to the consumption of gasoline. Although estimates are very scarce (and not consistent in their definitions of recreational travel), data seem to indicate that recreational travel could account for between 15-30\% of all personal (non-commercial) automobile use (Shimazu at CalTrans, 2/23/78; Gold 1976:174). Nationwide in 1975, personal passenger vehicles consumed between 11.5 and 22.9 billion 
gallons of gasoline in recreational travel; or between 103 and 205 gallons per personal registered vehicle (Department of Transportation 1977:84).

\section{LACK OF POLICY FOR RECREATIONAL TRAVEL}

Despite the importance of pleasure trips in terms of economic impact, individual lifestyles and expenditures, congestion and pollution in outdoor areas, and fuel consumption, there are virtually no policies developed specifically for recreational travel. A survey of state and local recreational plans, published after the Arab oil embargo, indicates that none of them mentions the relationship between energy conservation and outdoor recreation (Gold 1978:114). Public agencies tend to plan, develop, and maintain transportation networks to accommodate the commercial transport and the commute trip (Golden Gate Recreational Travel Study, September 1975:5). Yet these networks must also serve other travel needs, which they do with varying degrees of effectiveness. On many statewide highway systems, weekend peak hourly volumes are two or three times as heavy as weekday volumes (Wolfe 1967:1) Recreational travel, on top of demands for non-recreational trip purposes, creates weekend peakloads that cause congestion, delay, and excessive energy consumption (Mehra 1975:3; Golden Gate Recreational Travel Study 1976:73).

Transit companies also do not formulate policy for recreational travel, feeling that their first priority is to operate for commuters and shoppers (Golden Gate Recreational Travel Study September 1975:6). On holidays and weekends, most simply run fewer buses to the downtown and rarely consider the kinds of modifications necessary to encourage recreational travel, such as different travel routes, facilities, service frequencies, or fare structures (Bradburn, $7 / 27 / 78)$. They seem to have neither the time, money, nor staff to be concerned (Mills at AC Transit 8/15/78). Once again, recreational transit remains in the hands of private operators who run tours and charters with apparent success, despite the American habit of using the automobile for recreational travel (Golden Gate Recreational Study 1974:A14 ).

D. IMPORTANCE OF THE RECREATIONAL TRIP IN TRANSPORTATION POLICY

The above material suggests that recreational travel is a target worthy of energy conservation policy. It is unlikely that transportation energy problems can be resolved by concentrating solely on the work trip, currently the national policy. Even if policy does manage to lessen 
energy consumed in the work trip, the automobile would still remain the important mode for all recreational trips. Consequently, public policy should also be designed to reduce the American population's dependence on the automobile for leisure trips and to conserve some additional transportation energy.

\section{E. FOCUS OF POLICY RECOMMENDATIONS}

One of the strategies a successful policy can follow is to encourage actions which people might well take even in the absence of any policy at all. During the fuel embargo of 1973-74, Americans did not cut down on the number of leisure trips they took. However, they did change the pattern of their recreational travel by:

1) travelling shorter distances for recreation (546 vs. 594 miles).

2) taking trips of somewhat longer duration ( 2.24 vs. 2.10 nights).

3) traveling in larger groups (2.42 vs. 2.28 persons).

4) combining business and pleasure trips.

5) using buses and trains for recreational travel (U.S. Travel Data Center 1975:3).

The overall rise in the use of these common carriers was achieved at the expense of the airplane as well as the automobile (U.S. Travel Data Center 1975:4) and was evident in business as well as recreational travel (U.S. Travel Data Center 1975:14).

In this chapter, we shall focus on policies which encourage use of common carriers, such as bus or rail, for recreational travel. The rationale is severalfold. Despite the general lack of data on leisure travel, some research is available on the use of transit for recreational purposes. Secondly, supporting recreational transit seems to involve fewer problems in terms of implementation and, possibly, cost because it amounts to a more diversified use of an existing investment. Thirdly, an emphasis on public transit enables population groups without access to automobiles more opportunities for enjoying recreational experiences.

It is not practical to assume that government policy will be able to affect all or even a majority of pleasure trips in the short run. However, some trips are likely to be more responsive to public policy; we have focussed our initial analysis on a specific trip type, the weekend trip. In the following section, we discuss the weekend trip and the characteristics which policy makers can address to effect a modal redistribution. 
II. WEEKEND TRAVEL

\section{A. TRIP PURPOSE}

According to the 1977 National Travel Survey (Preliminary), almost 31 million households took weekend trips during the first three months of that year. Since this survey omits all trips under 100 miles in length, even these most recent data could underestimate the total number of weekend trips. Weekend travel represents about $40 \%$ of all trips over 100 miles taken in the United States; this percentage breakdown has remained approximately the same since 1972 . was :

of all weekend travel, the main purpose of the trip

$\begin{array}{lrlr} & \% & & \% \\ \text { visit friends/ } & 48.8 & \text { business/conventions } & 7.5 \\ \text { relatives } & & & \\ \text { outdoor recreation } & 14.6 & \text { personal/family affairs } & 9.7 \\ \text { entertainment } & 9.3 & \text { shopping/medical } & 1.1 \\ \text { sightseeing } & 2.6 & \text { other } & 4.5\end{array}$

If visits to friends and relatives are included, then fully $75 \%$ of all weekend trips are devoted to leisure and recreation. If we omit such visits, then recreational travel accounts for $26.5 \%$ of all weekend trips. However, this data could be biased downward because of the time of year during which they were collected (January-March 1977). For example, other sources have indicated that recreational travel could represent as much as $33 \%$ of total weekend trips (Mehra 1975:3). The 7\% difference could be due to the inclement weather of the early months.

\section{B. TRIP ACTIVITIES}

On weekend trips, the activities in which people engaged were:

$\begin{array}{lrlr}\text { museums/historic areas/ } & & \% & \% \\ \quad 16.9 & \text { fairs/concerts/sports } & 20.7 \\ \text { swimming } & & \text { events } \\ \text { hiking/walking } & 3.7 & \text { picnicking } & 4.7 \\ \text { ice/snow activities } & 10.0 & \text { camping } & 3.7 \\ \text { boating/sailing } & 11.5 & \text { outdoor games/sports } & 6.7 \\ & 2.0 & \text { fishing } & 4.9 \\ & & \text { other } & 14.5\end{array}$

It is again possible that the seasonality of the data has affected the above results. Differentiating among activities is important because the type of activity which occurs at a site can affect visitors' choice of transportation mode. For example, hikers may be more likely to ride buses than are beach visitors. This may be due to the 
buses' lack of storage space - an inconvenience for people travelling. with towels, bathing suits, beach toys, etc. to the shore- and perhaps to the fact that the hiker enjoys the opportunity of being picked up and dropped off by a bus at different spots along the hike (Goodrich and Solnit 1975;11-12). Therefore, policies promoting the use of common carriers should be aimed at activities requiring minimal equipment. Policies should also focus on activities like skiing which attract people from large metropolitan areas to a specific site and require little travel at the site.

\section{MODAL CHOICE AND VEHICLE OCCUPANCY}

While travelling on weekends, the modal split broke out to:

$\begin{array}{lrrr} & \% & & \% \\ \text { auto } & 77.3 & \text { bus } & 4.0 \\ \text { truck } & 9.8 & \text { train } & 1.0 \\ \text { airplane } & 6.5 & \text { other } & 0.3\end{array}$

It is likely that the car is used more to give flexibility in timing and routes than to extend the distance travelled. A person can come and go when it is most convenient, selecting a route that is scenic, speedy, close to accommodations, etc. In addition, the automobile offers the recreationist mobility at the destination. Local, on-site mobility is a crucial factor for several reasons. One is the need to carry heavy or cumbersome baggage and equipment around the recreational area. It is also important for a person at a resort or camp several miles from shopping, medical or other facilities.

Vehicle eccupancy for weekend trips and recreational travel tends to be $33 \%$ greater on the average, than for all other trip purposes (Mehra 1975:5). The average vehicle occupancy for outdoor recreational travel was 3.06 persons per vehicle. However, vehicle occupancy does vary depending on the type of recreational area and the distance travelled. For example, the lowest occupancy ( 2.87 people per vehicle) seems to occur at predominantly day-use, water-oriented sites, while the highest occupancies $(3.41$ people per vehicle) occurred at scenic areas of national reputation and catering to families. Also, the occupancy rate generally increased as did the distance travelled (Pigman 1972:4).

This may suggest that public policy should focus on certain types of trips to encourage transit use: for example, the shorter weekend recreational trip (specifically to areas proximate to SMSA's), trips to water-oriented sites, or for particular activities (e.g., ski trips). On family trips, with their higher vehicle occupancies, the car is an energy-efficient form of transportation. 


\section{CHANGES IN WEEKEND TRAVEL}

The modal choice for weekend travel has been changing slightly:

$\begin{array}{lrrrc} & 1972 & 1974 & 1977 & 1972-77 \\ & \% & \% & \% & \% \text { Change } \\ \text { auto/truck } & 88.9 & 88.6 & 87.1 & -1.3 \\ \text { air } & 7.2 & 6.3 & 6.5 & -0.7 \\ \text { bus } & 2.7 & 4.1 & 4.0 & +1.3 \\ \text { train } & 0.4 & \text { n.a. } & 1.0 & +0.6\end{array}$

Although the auto is still the overwhelming favorite for weekend trips, its use as a percentage of total travel has been declining slightly since 1972. The use of buses and trains increased a bit, although these two modes together only account for $5 \%$ of all weekend trips. This may be true because common carriers such as rail and bus only meet the transportation needs of the weekend traveller. In contrast, the automobile serves other functions as well. Most people do not travel to penetrate the countryside or the solitary wilderness. They want to remain close to the safety, comfort, and shelter of their cars (Maude 1971:73). A pleasant view and a place to picnic are what are necessary and desired. This means that the car is more than a travel vehicle but also a means of storage and shelter. Thus, policies to lure people out of their cars for weekend travel will have to provide more than another form of transportation.

III. THE FLOWCHART: DECISION-MAKING FOR THE RECREATIONAL EXPERIENCE

\section{A. AN AID TO POLICY DESIGNERS}

The diagrams, Figures 1 and 2, provide a tool to view the recreational experience in its entirety. The recreational experience is represented as a system: a set of major components and their interrelationships. The relationships examined depend on the particular problem at hand an on the interest of the policymaker. By depicting the recreational system, both in its internal linkages as well as the environment which affects it, we note some components that DOE policy makers could affect without altering the entire socioeconomic and political framework of the country.

The flowchart, Figure 2, can aid decision-makers in a variety of ways:

1) It may help planners in other agencies design recreational sites which encourage travellers to use an energy-efficient transportation system. 
2) It may illuminate some factors policy makers need to consider if their objective is to restrict automobile use for recreational travel.

3) It may suggest the recreational groups (and their particular needs) that must be served by transit because they have no modal alternatives.

4) It may help decision-makers evaluate the effectiveness of a particular policy design.

This analysis seeks to determine which components of the system could be altered to achieve a greater balance between the automobile and other modes for recreational travel. Through the flowchart, Figure 2, it develops an informational strategy for recreationists so that transit will become a "real alternative" to the automobile for leisure trips. The transit trip is defined as one made by bus, rail, or ferry boat or by automobile with a transfer to/from one or more of the above modes (Goodrich and solnit $1975: 54)$.

\section{B. THE ORIENTATION OF PREVIOUS RESEARCH}

There has not been much research on transit use for recreational travel. Most recreational travel studies have focussed on such factors as travel characteristics (time or cost), attributes of the traveller (income or auto ownership) and the attributes of the site (leisure activities or relative attractiveness). Those studies can be grouped into four categories: site-specific descriptive or inventory studies, behavioral studies, econometric models and travel models often premised on the work trip (Teal 1976:3-9). Many of these models are of limited userulness, because they simplified the system such that important components and relationships were eliminated.

Several researchers believe that the major obstacle to understanding recreation and tourism is the lack of knowledge on user preferences. The peculiarities of recreational travel and its causes have to be better understood before models predicting recreational travel can be used to evaluate the impact of transportation and recreation policies on the public, the natural resource base and the recreation and transportation facilities (O'Rourke 1974:146). The individual's motivation for and perception of recreational resources utlimately determines trip direction, distance, frequency and length.

\section{FOCUS OF THIS INVESTIGATION: USER'S DECISIONS}

We suggest that the selection of a travel mode requires a choice by the recreationist. In order to develop a more balanced recreational transportation system, public policy 
should also stress the user of that system. Our own description of the system focuses on the way the user decides to adopt a new mode of travel.

The system depicted in Figures 1 and 2 is based on research by Marion Clawson and Jack Knetsch (1963) for Resources for the Future. They have divided the recreational experience into five phases:

1) planning or anticipation

2) travel to the recreational site

3) recreation on the site

4) travel from the recreational site

5) recollection

\section{THE FIVE PHASES OF THE RECREATIONAL EXPERIENCE}

1. PLANING OR ANTICIPATION is the first phase. The family or travelling group decides where and when to go, what mode to use, who will go, where and how long to stay, what to do, and what route to follow. These decisions are listed in order of their importance (National Advertising Company 1972:9). Other major considerations of each decision include how much the family can afford to spend and what equipment and supplies are necessary. This phase typically occurs within the recretionist's own home, with the resources available there. Many of the choices made at this point are tentative, but much of the trip's major framework will be laid out somewhat in advance. More detailed planning will occur later, depending on the duration of the trip. For example, for a weekend trip to the regional park, one might not write away for trail maps, whereas this might be necessary for the two week vacation to a national park.

2. TRAVEL TO the recreation site is the second major phase. Nearly all outdoor recreation involves travel to the site. It is not uncommon to spend as much time travelling to an area as will later be spent relaxing there. Travel costs are frequently some of the highest trip costs. Travel may account for between $25 \%$ and $40 \%$ of the total trip cost, yet travellers are often unable to estimate trip costs accurately. While travel is often an enjoyable portion of the trip, travel time is a critical variable in the selection of a mode and route. The final choice of route is often made as the trip progresses and depends on particular activities in which the group wishes to engage along the way.

3. ON SITE experiences are the portion of the trip most often associated with "recreation". The activities undertaken here and the amount of time devoted to them usually provide the basic purpose for the entire trip. The accommodations and services available and the transportation around the site are also important factors affecting decisions made for this part of the recreational experience. 
4. TRAVEL FROM is the fourth major phase in the experience. The end point is the same as the origin of the "travel to" phase, but the route and time spent in transit may vary considerably. The kinds of activities engaged in and the type of services the group may desire or can afford often differ greatly on the return trip.

5. RECOLLECTION is the final phase in the recreation experience. Policymakers should not ignore this phase, since recollection generally forms the basis for planning and making decisions for the next recreational experience. The traveller can receive certain information which may not be worthwile during this trip, but which he/she could incorporate into the next one, (e.g., the availability of a shuttle bus on the recreation site).

\section{E. THE SYSTEM}

The flowchart, Figure 2, is divided horizontally into these five phases. Each phase incorporates a number of decisions which must be resolved before the next phase can be entered. The vertical divisions represent the factors influencing each decision and the actors who somehow affect these factors (e.g., direct provision, regulation).

INFORMATION: Information is written or verbal communications which both inform the recreationist once at the site and persuade him/her to visit a place, select a travel mode, pick a travel route, etc. (Teal 1976:4-10). Eleven information sources have been identified, as indicated by the eleven compartments of each box. At each decision point, some of the compartments will be blank, as not all information sources are utilized. This representation points out which information sources are most utilized or where there may be gaps in the flow of information.

CONSTRAINT: The constraining factors are also contained in a box and include institutional arrangements, resource availability, economic realities, personal family situations, etc. These are factors that might prevent the recreationist from freely chosing certain travel options.

CRITERIA: This box reveals the factors which travellers consider at various phases of the recreational experience. Decisions on criteria enable travellers to tailor their trips to their particular needs.

ACTORS: Lines connect each of the boxes to the primary actors involved. The actors are enclosed in circles to distinguish them from factors. 


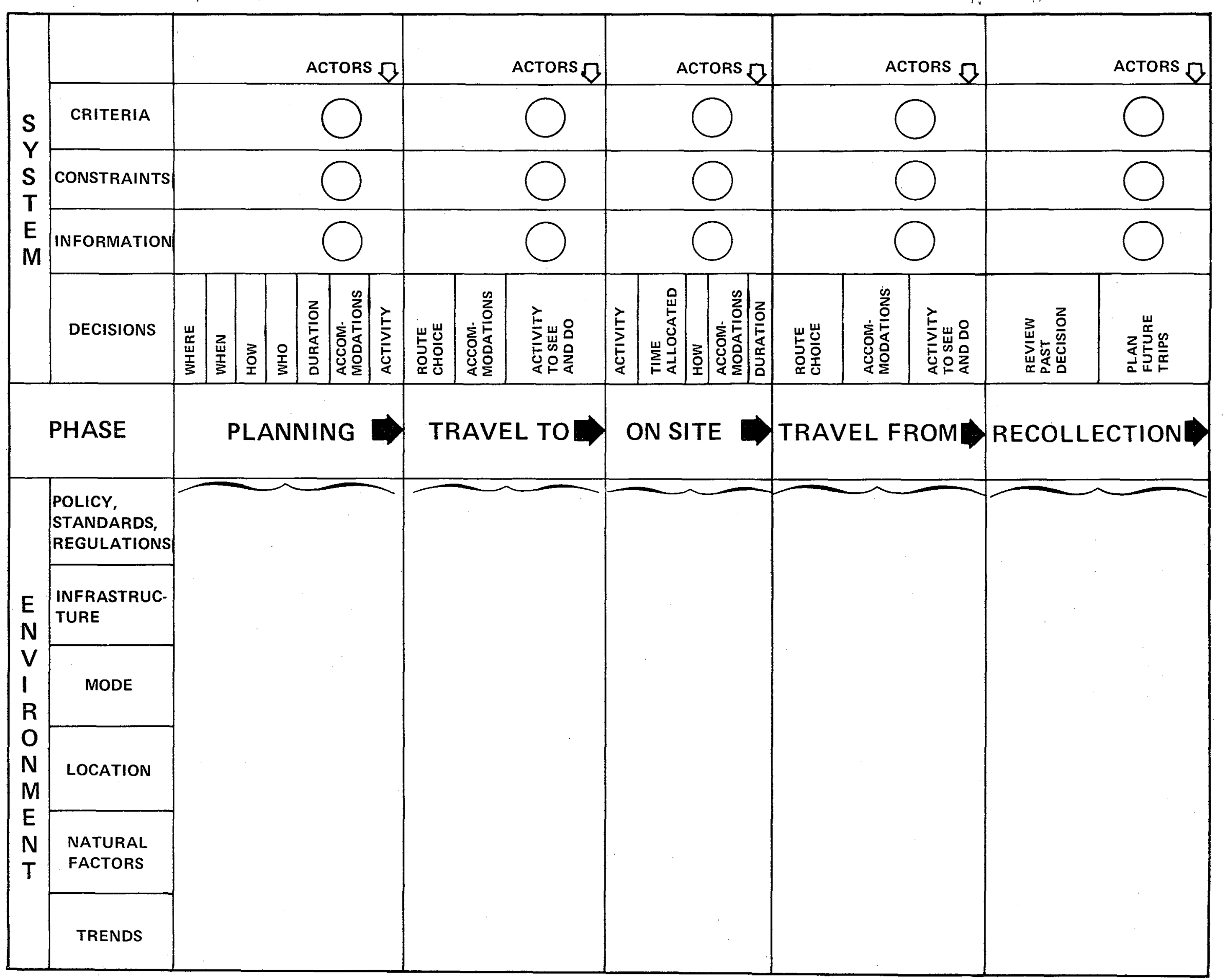

FIGURE 1. DECISION-MAKING FOR THE RECREATIONAL EXPERIENCE 



\section{F. THE ENVIRONMENT}

The recreational system depicted in the flowcharts -hould be understood in the context of the environment in which it has and is still developing. The environment includes factors that are revelant to the recreational experience, such as the location of highways,but which specific actions within the recreational system cannot affect very much.

SOCIAL TRENDS: Recreational experiences are constrained and molded by cultural trends. Recreational patterns are changing as leisure time and discretionary income increase. For example, the rising use of recreational vehicles and camping equipment means that more people are going to distant park areas for their recreational experiences.

LOCATION: The general socioeconomic system is responsible for the location of many recreational areas and their support facilities. These are governed by essentially the same laws which determine the location of any business. The design of the automobile and the availability of alternative modes of transportation can also be attributed to this system. Decisions on travel modes among locations are often based on the profit motive for the carrier rather than efficient transportation for the traveller.

INFRASTRUCTURE: The physical infrastructure which supports the travel industry, such as highways, railroads and airports, is located to meet needs other than those of recreational travel. Public policy has tended to plan, develop and maintain regional transportation networks to accommodate the commute or commercial transport trip. These networks may serve other travel needs, sometimes badly and sometimes well. The available infrastructure often determines what mode a traveller may chose and forecloses other options.

POLICY OR REGULATION: The government intervenes through various agencies in the setting of transportation rates, placement of holidays, acquisition of recreational facilities or scenic areas, the regulation of common carriers, etc. It is often fragmented and works with contradictory purposes. The policy or regulatory decisions are often not made in light of energy consumption or recreational needs. For example, not until 1962 did national recreational policy begin to consider acquiring land near metropolitan areas where recreational demand was highest. Up to that time, recreational policies had emphasized remote wilderness experiences. The Outdoor Recreation Resources Review Commission's report was the first indicator of need for recreational areas on the outskirts of urban centers. (Goodrich and Solnit 1975:28-29). 
NATURAL FACTORS: These are probably the most elusive factors for policy designers. For example, a certain amount of transportation energy will be consumed in recreational travel to distant sites. Since policy makers can do nothing about the location of the site, their emphasis should be on making this travel as energy efficient as possible.

\section{POLICY DEVELOPMENT FOR PHASE 1 "PLANNING THE TRIP"}

With the aid of the flowchart, Figure 2, we have examined the recreational system to understand why the present modal distribution in weekend recreational travel exists. We have identified which aspects of the system need to be addressed to alter the modal distribution, increase the use of public conveyances, and thus conserve some of the energy consumed in recreational travel. In the text, underlined items refer to factors identified on the flowchart. The underlining should assist the reader in following both the text and the flowchart.

Our analysis revealed that information flow is a very weak link in the decision to use or not to use transit for recreational trips. The information system appears to be biased to push people to a certain modal choice - the private automobile. Although deficiencies in the information system are obviously not the only reason why people tend to drive to recreational areas, the gaps are serious enough to merit remedial action. For example, the Golden Gate Recreational Travel Survey found that the most powerful factor affecting transit patronage is the knowledge recreationists have about the system and the service (Goodrich/Solnit 1975:14) Consequently, our policy strategies will deal with strengthening the information system.

\section{A. INFORMATION PROBLEMS CONCERNING MODAL CHOICE}

1. Occurrence of the Modal Decision in the System

An examination of this phase of the recreational experience reveals that the "how to go" decision (i.e., what mode to take) is made after two other major decisions, "where to go" and "when to go" (National Advertising Company 1972:9). These first two decisions may determine the modal choice for the recreational trip and possibly eliminate transit as an option. For example, the recreationist may select a weekend destination to which transit does not have access or he/she may pick a departure time not consistent with transit scheduling. 
auto be made available at these early decision points, even if people do not solicit it directly. Prior to a recreational trip, most people do seek out information (National Advertising Company 1972:14). Even for short trips, between 60-75\% of recreationists plan their trip a day or more in advance (Economic Research Associates 1975:49). They are especially interested in "hard copy" material such as pamphlets, brochures, and maps for trip planning (Economic Research Associates 1975:26).

\section{Orientation of the Information Source}

Why isn't transit information generally available at this stage of the trip? A closer look at Figure 2 reveals that the primary sources of information for the "where" and "when" decisions (information level) are not geared toward enhancing transit use.

Despite their desires for written material, most people turn to friends and relatives as their main source of recreational information (National Advertising Company 1970:3; Economic Research Associates 1975:25). While friends may be aware of recreational transit, they do not have the necessary information (routes, timetables, costs) to sway the modal choices.

For those who do obtain written material, little detail on transit possibilities is available. Yet, if transit nformation were included with recreational promotional material, it would reach people when their decisions were fluid and more susceptible to suggestions. Even if recreationists chose not to use transit for that particular trip, the information would still be available for the next one.

The second most important source of information for the "where to go" trip is maps (National Advertising Company 1972:14), which are biased toward auto travel, since they rarely indicate anything more than how the road network connects points of interest. As some of the major suppliers of maps are the motoring clubs, such as AAA, they are not likely to promote any other travel mode (Teal 1976:10). This same gap is also present in many guide books, brochures, and pamphlets: they have information on the site itself, but access information is limited to maps of the nearby roads and highways. Once again, the problem may lie in the bias or ignorance of the information suppliers. Travel agents are one of the prime sources of recreational information, yet they do not normally arrange transportation on buses or trains, except for Amtrak, since these organizations will not pay for their services. The agents must rely on the material that is available to them, and the alternative transportation services are often not part of this network (Teal 1976:6-9). Since travel agents rely on return 
customers and word of mouth advertisng, they want to ensure a pleasant travel experience. The agent may thus recommend a rental automobile over public transit since the latter is traditionally unreliable, infrequent, etc. (Teal 1976:6-9).

Public agencies which manage recreational sites, such as the National Park Service, have traditionally overlooked what goes on outside their boundaries (Edward Sullivan, $8 / 18 / 78$ ) and are frequently unaware of transit opportunities to their area. Pamphlets and brechures supplied by both federal and state park systems provide the little travel information other than a small map of the access roads to the site. Even if transit services are mentioned, route and time schedules are rarely supplied, nor are transit telephone numbers provided (Hough at Golden Gate Transit Authority $8 / 17 / 78$ ).

Only at the third decision point ("how to go"), do transit operators begin to influence the planning phase of the recreational trip. Even if transit has not been eliminated as a modal choice, there are still problems in relaying transit infermation to the recreationist. The first difficulty is that transit information and tickets are generally available only from the transit operators themselves and not, for example, from travel agencies. Transit operators often do not advertise in the travel sections of news Dapers or magazines. This lack of publicity forces recreationists to write or call for information, which can be a problem. People have little idea of where to write or call, and the effort involved in obtaining addresses and telephone numbers can prove to be too difficult (National Advertising Company 1972:17). The time delay involved in obtaining information may deter people from soliciting it, particularly for the short weekend trip.

Transit companies often fail to emphasize the trip as part of the recreational experience. Fun (criteria level) is the principal purpose of any recreation trip, yet most tran= sit operaters --except for the charter groups and tour companies-- do not promote themselves as a pleasant and relaxing way to travel. The market for recreational transit might increase if common carriers adopted some of the advertising and promotional techniques of the tour operators (Golden Gate Recreational Travel Study, December 1974:A-14). Instead, they tend to emphasize low costs, rather than comfort, convenience, educational opportunities, sightseeing, (criteria level) etc. Although cost is obviously a very important factor, the others are also crucial variables in the level of service provided by long distance transportation (Smith 1977:17). 


\section{Interface With other Decisions}

The next information gaps occur at the decision points "Activities to See and Do" and "Accommodations". Recreationists prefer the private automobile for travel because it offers the most mobility and flexibility (criteria and constraints level) at the destination (opinion Research Corporation 1962:28; Economic Research Associates 1975:23; Smith 1977:14). People do not know how they will travel around the site once they get there, nor of what the "requirements" of the recreational experience will be: necessary clothing and shoes, available food and other per = sonal services, weather conditions, recreational equipment (criteria and constraint level). People travel in a car because it allows them to carry along all of the above, whether it is needed or not. Taking the bus requires more planning and preparation for the recreational activity. Informing people as to what they will need at the recreational area and what is provided (e.g., shuttle bus, bicycle rental) help offset the auto's perceived flexibility (Economic Research Associates 1975:22).

The search for accommodations represents another opportunity, thus far relatively unutilized, for the dissemination of transit information, in terms of both "travel to" and "at the site". People must often make reservations in advance at campgrounds, motels, ski facilities, etc. Transit information could be provided to the recreationist when he/she is at the point of making these other decisions. Discounts could be available which link travel modes with accommodations.

V. OBJECTIVES AND STRATEgIES FOR "PLANNING THE TRIP"

A. CREATE AND/OR STRENGTHEN LINKS BETWEEN TRANSIT INFORMATION AND THAT OF OTHER RECREATIONAL SOURCES

This objective speaks to the need for injecting transit information early in the recreational planning process. Its purposes are to affect those actors which are presently biasing the information system away from transit and to insert transit operators as a major actor at an eariier decision point.

\section{Information Systems Using Personal Sources}

Since friends and relatives are the primary sources of information, transit operators should design information systems which emphasize and utilize these personal sources. This could include: 
a) Stimulating direct face-to-face contact with potential recreationists as well as citizen participation. These are among the most effective methods for distributing information about alternative transportation systems (Economic Research Associates 1975:144). These include public workshops and speaker programs, which tend to have more impact if they are channeled through existing public interest groups, such as conservation and/or neighborhood organizations.

b) Making pamphlets, flyers and brochures on transit opportunities available at public places. Distribution sites could include the park entrances as well as libraries, schools, and neighborhood commercial areas, such as supermarkets. Ideally, people would pass them on to family and friends.

c) Generating more transit publicity in newspapers woh as feature articles on recreational areas. About $20 \%$ of recreationists use newspapers, particularly the Sunday travel section, as a source of information on "where to go" (Natonal Advertising Corporation 1972:8).

PRIMARY ACTOR: Transit operators will have to increase the scope of their current marketing efforts. This may include hiring additional personnel to act as a liaison between the transit company and local public interest groups and local media. Increased printing and distribution of promotional materials may also be necessary.

\section{Coordination Between Recreation and Transit Agencies}

Since public agencies often manage recreational sites, there should be more coordination and contact between them and transit operators. The National Park Service, for example, should enlarge the scope of its responsibility to include:

a) assuring that all park brochures contain information on transit.

b) planning access for and coordinating on-site travel modes (e.g., park shuttle) with local transit.

c) supplying as much information as possible about the site, so recreationists will not feel so compelled to maximize their flexibility by travelling in an automobile.

PRIMARY ACTOR: Public recreational agencies will have to increase their coordination with transit agencies. This may entail retaining a transportation planner for their staff. 


\section{Joint Information Dissemination}

Much supplemental information on recreational activities is available through a variety of sources, including media. The travel industry alone encompasses five sectors: transportation, food/beverage, lodging, entertainment/attractions, and goods and services. This represents a variety of actors with whom transit operators could enter into formal agreements to disseminate promotional materials or to organize other "package deals". For example:

a) ski reports are often aired on the radio or telephone; one sentence could mention transit access to the site.

b) back packers and hikers must often purchase some equipment before a trip and transit information could be available at these stores.

c) chambers of commerce or tourist councils could include transit schedules (both to and on the site) when they receive requests for tourist information.

d) hotels and motels could send out transit information when they take reservations.

e) transit tickets could be part of a recreational "bundle" purchased by tourists (e.g., transit tickets included in the price of ski lift tickets, restaurant meals, shopping purchases).

PRIMARY ACTOR: Transit operators, chambers of commerce, retail outlets for recreational equipment, food and lodging sector, recreation industry, etc. Transit operators will be primarily responsible for contacting the various actors in the recreational travel industry. Each transit operator will have to seek out the appropriate agents located in the recreational area.

\section{B. DESIGN A CENTRALIZED SYSTEM OF RECREATION/TRANSIT INFOR- MATION}

The transit information gap is not eliminated by multiplying the number of information sources. Simplifying the communication procedure and bringing the various actors together is also necessary. First of all, individuals may not be aware of the large variety of information sources. Secondly, individuals are reluctant to use many sources for recreational information but are more willing to use a single source (Economic Research Associates 1975:133). Contacting multiple sources is time-consuming and involves locating many different addresses and telephone numbers. In particular, obtaining information on transit may be a low priority. Centralizing the information system encourages more people to plan their weekend trips and makes it easier for them to learn about recreational transit opportunities. 


\section{Central Information Address}

In a survey of recreational travellers, $90 \%$ of the respondents indicated that a central and well-known address for recreational information would encourage them to write ahead of time (National Advertising Company 1972:16). A strong emphasis on transit availability would be necessary to attract people's attention and have them begin considering alternatives to the car. The information system could be organized either in terms of:

a) geographic location - i.e. what recreational opportunities are there around a particular city or metropolitan area and what travel options are available. The information on transit should be as detailed as possible, emphasizing costs and any special features (group rates, educational lectures, storage for recreational equipment); or

b) weekend activity - i.e. where are the skiing or hiking/camping sites and what are the travel options to them.

PRIMARY ACTORS: Transit operators, chambers of commerce, the food and lodging industry, private recreation entrepreneurs, federal, state, and local government, etc. The multitude of actors and the complexity of the task suggest that the federal govermnment initiate policy implementation, albeit on a limited basis. The federal government should probably confine its efforts to public recreational sites so as not to infringe on the activities of private entrepreneurs, such as travel agents.

\section{Toll-Free Telephone Number}

A central telphone number might be more effective than a commmon address since it could be used for last-minute planning (Economic Research Associates 1975:140). Like the address, however, the telephone system could also be organized around either geographic location or weekend activity. A acronym telephone number, such as WEEKEND or FUNTRIP, would be ideal. Some components of this system might be:

a) an information package, describing the recreation area or activity site requested as well as available transit options. A trip planning map indicating transit routes from the individual's home to the recreatinal site could be mailed upon request.

b) telephone inquiries for specific information on, for example, weather conditions, travel time, fees, or possibility of joining a tour could also be handled.

c) promotion of transit usage by stressing the negative aspects of automobile travel: crowded access roads, lack of parking, environmental impacts, hazardous road conditions, etc. 
PRIMARY ACTOR: Same as above.

C. STRESS TRANSIT'S RECREATIONAL POTENTIAL IN THE INEORMATION AND MARKETING SYSTEMS

The function of a transportation system is to carry people from one place to another in the minimum time compatible with reasonable cost and convenience. Typically, transit operators have a great deal of experience in this area but have little "recreation" experience. In recreational experiences, travel time is often of little importance if the journey itself is "fun" (Great Britain Countryside Commission 1974:14). For the recreationist, travel time can be mitigated by a variety of factors: the scenic quality of the trip, the fun value of the trip when travelling with a group of friends, or the ride itself, such as a trip on the train or ferry (Goodrich/solnit 1975:7-9). The transit operator should consider these special factors when promoting its services.

\section{Market Segmentation}

Transit operators should adopt a market segmentation approach in their efforts to promote themselves for recreational travel. This could mean:

a) by population group (the elderly, ethnic minorities), thus enabling transit operators to structure information, recreation, and transportation programs to meet the specific needs and desires of an identified group. The trip becomes more appealing to this group since it is "planned" for them. This approach should stress such factors as: compatibility of passengers (no elderly with children); educational interests (lectures on history, wildife, current events); en-route entertainment (music and games); and route and time scheduling (locate near tourist hotel areas).

b) by activity (skiing, hiking), thus enabling transit operators to structure the program to match the features of an identifiable recreational activity. Special aspects might involve: weather and topographic conditions and information on evening entertainment and special events. Such a program would allow transit operators to narrow their marketing efforts to a very well-defined and well-patronized trip.

PRIMARY ACTOR: Transit operator, local recreational entrepreneurs, special interest organizations, civic groups, etc. 


\section{Emphasize Enjoyment}

Media campaigns should emphasize the "fun" aspects of the trip. This could involve:

a) focusing on factors such as trip comfort and intransit entertainment issues the airline industry has recognized for years. The specific techniques utilized will depend on the criteria of "fun" that specific user groups have. These are discussed above.

b) newspaper coverage and brochures should highlight modes that are viewed as part of the recreation experience itself and thus mitigate travel time. Such modes include ferries that may connect with auto routes. Emphasis should also be placed on unusual transport systems that provide access to places not easily reached by other means. This might serve to shift trips from automobile-oriented sites.

PRIMARY ACTOR: Transit operators, newspapers and magazines, advertisng companies.

\section{BIBLIOGRAPHY}

American Automobile Association

1971 And Away We Go - a Survey of the Travel Habits of the Members of the AAA. Washington, D.C. October.

Booz, Allen \& Hamilton

1974 Sensitivity of the Leisure Recreational Industry to the Energy Crisis. Washington, D.C.: Federal Energy office.

California Department of Commerce, Division of Tourism 1972 Objectives and Programs to Stimulate California's Tourism Industry. Sacramento, California.

Cicchetti, Charles C.

1972 Outdoor Recreation and Congestion in the United States: Population, Resources, and the Environment. Washington, D.C.: Commission on Population Growth and the American Future.

Clawson, Marion \& Jack L. Knetsch

1963 Outdoor Recreation Research. Washington, D.C.: Resources for the Future, Inc. Reprint Number 43. November. 
Economic Research Associates

1975 Design, Monitoring and Evaluation of Information Systems. San Francisco, California: Golden Gate Recreational Travel Study. April.

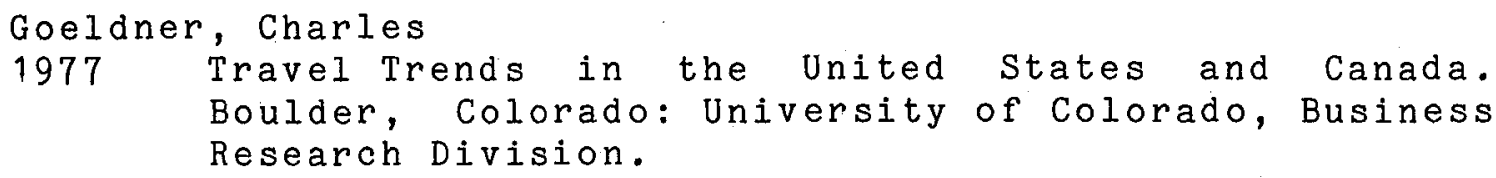
Boulder, Colorado: University of Colorado, Business Research Division.

Gold, Seymour M.

1978 Recreation Planning for Energy Conservation. Urban Ecolegy, Volume 3 .

1977 Recreation Planning for Energy Conservation. Inter = national Journal of Environmental Studies, Volume 10 .

GOLDEN GATE RECREATIONAL TRAVEL STUDY

1976 Summer of 1975 Findings, Staff Report 3 . San Francisco, California. April.

19751974 Data Book, Staff Report 2. San Francisco, California. September.

1975 Auto Travel in the Golden Gate Recreational Travel Study Area, Staff Report 1. San Francisco, California. April.

1974 Summary Report: Preliminary Transportation Alternatives. San Francisco, California. December.

Goodrich and Solnit

1975 The Golden Gate Recreational Travel Model. San Francisco, California: Golden Gate Recreational Travel Study. September.

Great Britain Countryside Commission

1974 Transport for Countryside Recreation. Welwyn Garden City, Hertfordshire: Robert Mathew, Johnson Marshall \& Partners.

Jones and Jones

1975 Stehekin North Cascades Transportation Plan. Denver, Colorado: National Park Service. 
Leonhardt, Karl

1973 Recreational Trip Characteristics and Travel Patterns. Olympia, Washington: State Highway Department. Research Report 11-2. June.

Maring, Gary E.

1971 Weekend Recreational Travel Patterns. Washington, D.C.: Federal Highway Administration. Highway Planning Technical Report no. 18. February.

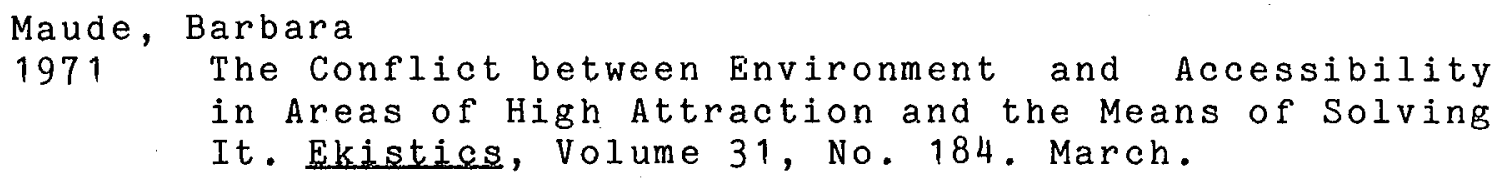

Mehra, J., and Bellomo, S.

1975 Weekend and Recreational Travel. AMV Technical Notes, Volume 11, No. 7. January.

National Advertising Company

1970 Impulse Travel: Changing Trends in Auto Vacation Travel. Argo, Illinois

1972 Psychographics of the Auto Traveler. Argo, Illinois.

Opinion Research Corporation

1962 The Domestic Travel Market. Princeton, New Jersey. June.

Pigman, J., Deacon, J.A., and Deen, R.C.

1972 Characteristics of Outdoor Recreational Travel. Lexington, Kentucky: Department of Highways. Research Report 350. December.

O'Rourke, Barry

1974 Travel in the Recreational Experience - A Literature Review. Journal of Leisure Research, Volume 6 . Spring.

Rodgers, Brian

1971 The Sociological Trends towards Greater Leisure, Car Ownership, and Car-Use. Ekistics, Volume 31, No. 184. March. 
Salinger \& Company, Inc.

1969 The Newsweek Travel \& Vacation Study . Norwood, Pennsylvania. May.

Senate Committee on Commerce, Subcommittee on Foreign Commerce and Tourism.

1974 Adequate Supplies of Energy to the Tourism Industry. Washington, D.C.: U.S. Government Printing Office. March 29 and April 1.

Smith, R.L. et al.

1977 Analysis of Long Distance Transportation Access to the Apostle Islands National Lakeshore. Madison, Wisconsin: Department of Civil \& Environmental Engineering, University of Wisconsin. August.

Teal, Roger et al.

1976 Tourist Traffic in Small Historic Cities: Analysis, Strategies and Recommendations. Washington, D.C.: Department of Transportation.

Travel Research International, Inc.

1969 And Many Goodly States and Kingdoms Seen. Harpers Magazine and Ihe Atlantic. September.

United States Travel Data Center

19751974 National Travel Survey. Washington, D.C.

Wall, Geoffrey

1973 Car Owners and Holidays. Town Planning Review, Volume 44, No. 2. April.

Wolfe, R.I.

1967 A Theory of Recreational Highway Traffic. Ontario, Canada: Department of Highways. Report RR128.

PERSONAL CONTACTS

John Adams, Chief of Park Planning

National Park Service, Western Region, San Francisco, Ca. 1 September 1978

Robert Babcock

National Park Service, Yosemite National Park, Ca. 1 September 1978 
Jack Bechtel, Planning

California Parks and Recreation, Sacramento, Ca.

31 August 1978

Robert Blau, Superintendent

East Bay Regional Park District, Oakland, Ca.

5 September 1978

Richard Bowser

Appropriate Technology Division, National Park Service

Washington, D.C.

1 September 1978

Dr. Norman Bradburn, Chairman-Department of Behavioral Science University of Chicago, Illinois

27 July 1978

Garrett DeBell, Environmental Specialist

MCA/Curry Company, Yosemite National Park, Ca.

6 September 1978

Gene Gardiner

AC Transit, Oakland, Ca.

6 September 1978

Kenneth Hough

Golden Gate Transit, San Rafael, Ca.

17 August 1978

Harvey Kriesberg

Chase, Rosen \& Wallace, Alexandria, Virginia

5 September 1978

Robert Lowes

MCA/Curry Company, Yosemite National Park, Ca.

6 September 1978

Mitchell Matsamura

Public Utility Commission, San Francisco, Ca.

6 September 1978

Michael Mills, Marketing

AC Transit, Oakland, $\mathrm{Ca}$.

11 August 1978

Douglas Nadeau

Golden Gate National Recreational Area

San Francisco, $\mathrm{Ca}$.

15 August 1978

James Straughn, Transportation Planner

Midwest Rocky Mountain Team, National Park Service

Denver, Colorado.

1 September 1978 
Edward C. Sullivan

Institute of Transportation Studies, Berkeley, Ca. 18 August 1978

Herbie Sansum, Public Information officer National Park Service, Yosemite National Park, Ca. 1 September 1978

Lee Whitehead, Director of Public Relations Greyhound Company, Phoenix, Az.

1 September 1978

Peggy Woodring Metropolitan Transportation Commission, Berkeley, Ca. 1 September 1978 
$\stackrel{3}{c}$ 
This report was done with support from the Department of Energy. Any conclusions or opinions expressed in this report represent solely those of the author(s) and not necessarily those of The Regents of the University of California, the Lawrence Berkeley Laboratory or the Department of Energy. 
TECHNICAL INFORNIATOI DIVISION

LAWRENCE BERKELEY LABORATORY

UNIVERSITY OF CALIFORNIA

BERKELEY, CALIFORNIA 94720 